\title{
Challenges and Realizing Path of Higher Education International Exchange and Cooperation in Yunnan under "The Belt and Road" Initiative
}

\author{
Chongyou Ruan* \\ The College of Arts and Sciences \\ Yunnan Normal University \\ Kunming, China \\ 807756298@qq.com
}

\author{
Yu Wang \\ The College of Arts and Sciences \\ Yunnan Normal University \\ Kunming, China
}

\begin{abstract}
Construction of "The Belt and Road" initiative is a major strategic conception with China's national pooling under varying domestic and international situations.The implementation of "The Belt and Road" initiative has provided new endogenous impetus and external opportunities for the internationalization of higher education in Yunnan Province. However, universities and colleges in Yunnan are facing challenges in terms of actual developing reality, low-level external exchange and cooperation both objectively and subjectively. Universities and colleges in Yunnan should strive for support from the national level and specific care from local government, promote cross-border education exchange and cooperation, cultivate internationalized talents, adjust the layout of disciplines and subjects, raise awareness of internationalization, improve the internationalization of management to actively integrate into the overall situation and construction of "The Belt and Road" initiative.
\end{abstract}

Keywords- "The Belt and Road" initiative higher education in Yunnan Province internationalization of higher education

\section{INTRODUCTION}

"The Belt and Road" initiative has brought important historical opportunity for the development of social economy in Yunnan Province, which plays an important role along with countries in this area with its particularity of location. As main body for the guarantee of the talents needed for the construction of "The Belt and Road" as well as communication route of Chinese culture to the countries along the routes, universities and colleges in Yunnan are shouldering magnificent responsibilities and faced with many challenges. This paper analyzes the current challenges Yunnan is faced with in international education exchange and cooperation among colleges abroad, then points out internationalization strategy for the development of universities and colleges in Yunnan to better promote the universities' service and support to our national "The Belt and Road" construction.

\section{UNIVERSITIES AND COLLEGES IN YUNNAN SHOULDER MAGNIFICENT RESPONSIBILITIES INTERNATIONAL EXCHANGE AND COOPERATION IN HIGHEREDUCATION UNDER “THE BELT AND ROAD”INITIATIVE}

Located in the ancient southern Silk Road route, facing the Southeast Asia, South Asia and West Asia, connecting the Pacific Ocean and the Indian Ocean to the Yangtze River, Pearl River, Lancang River and the Mekong River to the sea border areas, Yunnan has its unique regional position. With its distinctive geographical advantages, Yunnan connects the Silk Road Economic Belt in its north and the Marine-time Silk Road in its south which make it an open bridgehead to the Southwest China area, strategic fulcrum of "The Belt and Road" construction as an important intersection, a communication channel hub of South and Southeast Asia countries as well as a significant industry transfer and industry base. Yunnan is an important platform and open window of exchanges and cooperation with South and Southeast Asia. The unique location advantage highlights Yunnan's status in "The Belt and Road" construction.

Yunnan, in the neighborhood of the countries along "The Belt and Road" area, has come to the forefront of reform and opening up, which has been totally converted from its comparative rear location and has seized a historic opportunity to overtake the curve. General Secretary Xi Jinping delivered an important speech when making investigation in Yunnan in January 2015, requiring: "Yunnan must actively provide services and integrate into the national development strategy, rush out a developing way to leapfrog in developing its economy, strive to become vanguard demonstration area of China's national unity progress as well as ecological civilization construction, radiation center of Southeast Asia, South Asia to compose the Yunnan chapter of China dream". During the Two Sessions in 2015, deputy Prime Minister Zhang Gaoli demanded the Yunnan delegation when reviewing the conference: "Yunnan must take actions in accordance with the requirements of the central government, practice the spirit of General Secretary Xi Jinping's important speeches, actively provide service and integrate into the national development strategy, participate in all "The Belt and Road" and the 
Yangtze River Economic Belt construction, build important bridgehead for opening policies to West China, promote leapfrog development and healthy and steady economic development to gain social harmony and stability." This has further clarified Yunnan's important role in "The Belt and Road" initiative.

As top-level design of international cooperation and exchange in education, "The Belt and Road" initiative has clear requirements for development of universities and colleges. In February 2016, the General Office of the Central Committee of the Communist Party of China and the General Office of the State Council issued "Opinions on Well Doing Works of Education Opening in the New Period" (hereinafter referred to as "Opinions"), putting forward that the central and western regions in China should consistently broaden and deepen their education opening and border areas should make use of geographical advantages to promote the education exchange and cooperation with its neighboring countries. With all the efforts, an education pattern combining with local conditions and characteristics has formed to promote education opening to the outside world [1].

For the implementation of the "Opinions", in August 2016, led by the Ministry of Education, the Action to Promote Education Co-building under the "Belt and Road" Initiative was formulated. The Action points out that the local propulsion should be highlighted to co-build "The Belt and Road" and to become "the subjectivity of areas along the routes", education opening must support the construction and related projects must land on ground. Provinces and areas related should make full use of their local advantages and local characteristics to respond closely to the overall layout; various schools and institutions at all levels should expand cooperation and exchange with countries along the routes, jointly promote education internationalization level and services to enhance capability of constructing "The Belt and Road" [2]. As an important subject of talent support needed for the construction of "The Belt and Road" in the southwest region and important subject of cultural communication with foreign countries along the routes, universities and colleges in Yunnan shoulder the responsibility of higher education international exchange and cooperation.

\section{CHALLENGES IN Higher EDUCATION INTERNATIONAL EXCHANGE AND COOPERATION UNDER "THE BELT AND ROAD” INITIATIVE FOR OF UNIVERSITIES AND COLLEGES IN YUNNAN}

For a long time, it is difficult for Yunnan to develop and improve its education because its location on the frontier and the lagging-behind economic development even though education was Yunnan's prime necessity as well as prime difficulty. "The Belt and Road" initiative has brought development opportunity for universities and colleges in Yunnan, but difficulties exist both objectively and subjectively in the higher education development situation, thus Yunnan is facing many challenges in higher education service and opening.

\section{A. Challenges Brought by the Lagging-behind Development of Universities and Colleges in Yunnan}

1) Small amount of universities and colleges and lack of high-level talents

According to statistics released from the China Education Yearbook 2015, in 2014, the number of colleges and universities in Yunnan took $2.65 \%$ across the whole country, among which higher vocational (technical colleges), undergraduate and graduate institutions accounted for $2.78 \%$, $2.49 \%$ and $2.78 \%$ respectively across the country, master's and doctoral students accounted for $1.8 \%$ and $0.7 \%$ respectively. Therefore, Yunnan is facing with difficulties of comparatively small amount of universities and colleges and incapability of high-level talents. (See table I).

TABLE I. CurRent DEVElopment of Higher EduCATION IN YunNAN

\begin{tabular}{|c|c|c|c|c|c|c|}
\hline Item & $\begin{array}{l}\text { Amount } \\
\text { of } \\
\text { universiti } \\
\text { es and } \\
\text { colleges } \\
\text { in } \\
\text { Yunnan }\end{array}$ & $\begin{array}{c}\text { Amoun } \\
\mathrm{t} \text { of } \\
\text { Postgra } \\
\text { duate } \\
\text { instituti } \\
\text { ons }\end{array}$ & $\begin{array}{c}\text { Amoun } \\
\mathrm{t} \text { of } \\
\text { undergr } \\
\text { aduatei } \\
\text { nstituti } \\
\text { ons }\end{array}$ & $\begin{array}{c}\text { Amount } \\
\text { of } \\
\text { vocationa } \\
1 \\
\text { institutio } \\
\text { ns }\end{array}$ & $\begin{array}{c}\text { Ratio } \\
\text { of } \\
\text { Master } \\
\text { student } \\
\text { s }\end{array}$ & $\begin{array}{c}\text { Ratio of } \\
\text { doctora } \\
\text { te } \\
\text { student } \\
\text { s }\end{array}$ \\
\hline
\end{tabular}

2) Insufficient construction of high-level teaching staff

From the perspective of the distribution of teaching staff's education level of universities and colleges in Yunnan, though the proportion of those who have a master's degree is roughly equal to the national average, the proportion of those who have a doctorate is far below the national average. According to the hierarchical distribution of professional teaching staff of colleges and universities in Yunnan, the proportion of those with vocational titles of associate professor and professor is also lower than the national average. In general, there is a shortage of high-level teaching staff in universities and colleges in Yunnan (see table II).

Studies have shown that, although currently there is strong desire in western scholars to flow, the overall flow frequency is not high. This partly reflects that the western universities have few scholars who are truly able to flow to more developed regions under the new competitive situation. At the same time, quite different from the mutual aid flows among universities and colleges in the east China, this mutual assistance among universities and colleges in Yunnan is very rare [3]. This research confirms the conclusion that the high level teaching staff in universities and colleges in Yunnan is very insufficient. 
TABLE II.

Proportion OF High-LeVEl TeAching StafF IN 2013

(UNIT: \%)

\begin{tabular}{|c|c|c|c|c|}
\hline & $\begin{array}{c}\text { Teaching } \\
\text { staff with } \\
\text { Doctor's } \\
\text { degree }\end{array}$ & $\begin{array}{c}\text { Teaching } \\
\text { staff with } \\
\text { Master's } \\
\text { degree }\end{array}$ & $\begin{array}{c}\text { Teaching } \\
\text { staff with } \\
\text { Associate } \\
\text { Professor } \\
\text { Title }\end{array}$ & $\begin{array}{c}\text { Teaching } \\
\text { staff with } \\
\text { Professor } \\
\text { Title }\end{array}$ \\
\hline $\begin{array}{c}\text { National } \\
\text { average }\end{array}$ & 18.7 & 35.5 & 28.9 & 12.0 \\
\hline Yunnan & 12.4 & 36.0 & 27.5 & 11.0 \\
\hline
\end{tabular}

Note: Data of table 2 are from website of PRC State Statistics Bureau: Statistics of professional teaching staff's academic degree and title, 2013

\section{B. Challenges Brought by the Low Level International \\ Exchange and Cooperation in Universities and Colleges in Yunnan}

1) Small scale of foreign students as well as comparatively low educational level

According to related statistical data from the Concise Statistics of Abroad Students of 2015 by the international exchange and cooperation department of the Ministry of Education, in 2015 colleges and universities in China receive a total of 397635 students, among which universities and colleges in Yunnan received 12078 foreign students, accounting for $3.04 \%$ of the total number of foreign students that year. Among the abroad students in Yunnan, most of them are studying for bachelor and master's degree, in contrast, not too many are studying for doctorate or vocational. The nonacademic students are mainly ordinary students and short nondegree programs students and there are not many advancedlevel students. In a word, the abroad students in Yunnan just amount to a very small scale and study for relatively low educational level (see table III).

TABLE III

DiSTRIBUTION OF ABROAD STUDENTS IN YUNNAN OF YEAR 2015(UNIT: PERSON)

\begin{tabular}{|c|c|c|c|c|c|c|}
\hline \multicolumn{4}{|c|}{ Degree students } & \multicolumn{3}{|c|}{ Non-degree students } \\
\hline $\begin{array}{c}\text { Undergr } \\
\text { aduates }\end{array}$ & $\begin{array}{c}\text { Master } \\
\text { degree }\end{array}$ & $\begin{array}{c}\text { Doctor } \\
\text { degree }\end{array}$ & Vocational & $\begin{array}{c}\text { Advanced } \\
\text { level }\end{array}$ & $\begin{array}{c}\text { Average } \\
\text { level }\end{array}$ & $\begin{array}{c}\text { Short-term } \\
\text { Exchange }\end{array}$ \\
\hline 3494 & 791 & 123 & 319 & 28 & 2583 & 4740 \\
\hline
\end{tabular}

Note: data in table 3 are from the Concise Statistics of Abroad students in China, 2015

2) Yunnan's Sino-foreign cooperative education lags far behind the eastern regions

Statistics from the Sino-foreign Cooperative Education Information Supervision Platform by the Ministry of Education, up to February 16, 2017, there are a total of 795 Sino-foreign cooperative education projects and institutions verified or reexamined by national education administrative departments, among which, Yunnan held only 9 projects, accounting for $1.13 \%$ in total, which is much lower than the eastern provinces; the total number of Sino-foreign cooperative education programs at the undergraduate level and above is 1,230. Among them, Yunnan holds 13 projects, accounting for $1.06 \%$ of the total number of projects in the same level in China, which is far lower than the eastern provinces. There are 111
Sino-foreign non-legal-person cooperatively-run institutions in China, while Yunnan has not established these institutions yet. The data shows that the development of Sino-foreign cooperative education in Yunnan lags far behind the eastern provinces.

3) Unbalanced development of various colleges and universities on international exchange

From the perspective of foreign exchange activities in colleges and universities in Yunnan, various performances are presented. First of all, comprehensive universities such as Yunnan University, Yunnan University of Finance and Economics, Kunming Science and Technology University, Yunnan Normal University and other universities have been relatively active in international cooperation and academic exchanges, while other universities are not very active. Secondly, academic exchange funds to the students who go abroad are varies. Short-term academic exchange program is more common in colleges and universities and some colleges and universities will sponsor some funds for students to participate in the study tour to a certain degree, but it is more common for students to go abroad at one's own expenses. Since cost is an important factor in international study, and the longtime underdeveloped economy in Yunnan has restrained students in Yunnan to participate in overseas exchange activities.

\section{Challenges Posed by Local Governments and Universities' Inadequate Response}

1) Local governments have not paid enough attention to the international education exchange and cooperation

With a weak foundation, international education exchange and cooperation of universities and colleges in Yunnan is relatively lagging behind the eastern regions in China, which means that Yunnan's disadvantage lies in aspects such as recruiting staff, attracting high-level international students and establishing Sino-foreign cooperation projects. Because of its remote location in the economically underdeveloped regions at the same time, colleges and universities in Yunnan usually find it very hard to get more social support and feedback. Although in recent years, China has strengthened support to higher education in the western areas and the policy tilt, but these favors are still not enough to reverse the current situation in the short term, colleges and universities in Yunnan still lag behind and the development of local colleges and universities mainly still rely on the support of local government. When the "Belt and Road" initiative has been raised, local government show great enthusiasm in planning and policy-making in succession to seize the development opportunity, but local finance focus mainly on the field of economy and trade, there is still a lack of sufficient understanding of the importance of higher education.

2) Participation mode of the old universities needs to be improved, while the participation of newly-established universities and higher vocational colleges is quite limited

Via an analysis of universities and colleges' official websites, Yunnan University, Yunnan University of Finance and Economics, Kunming Science and Technology University, Yunnan Normal University and Yunnan Minorities University do well in terms of international academic exchange and 
cooperation, these colleges and universities generally have established administrative agencies and international education institutions taking care of foreign exchange and cooperation, providing services to foreign students, promoting abroad student recruitment and training, but they still have the problem that the most commonly used teaching language is Chinese, which is very unfavorable to recruit and train students. In the newly-established universities and colleges, not many of them have similar administrative and teaching institutions to serve international cooperation and exchange. Even organization bars of some of the colleges and universities' official website show that they have established international exchange section for the exercise of administrative functions of international exchange as well as international institution to perform the function of teaching, but actually both are united into a same organization. The functions of those institutions usually include promoting intercollegiate exchange of visits between teaching staff and students with other countries. Some these international institutions do not actually recruit abroad students, nor do they set training courses for these foreign students because they are engaged in teaching foreign languages to Chinese, whose function is only equivalent to general foreign language school or preparatory class. The participation of private universities and vocational colleges in international exchange and cooperation is not much, either. Although some of these universities and vocational colleges have set up international exchange and communication institutions, they have not carried out any substantive activities.

3) Internationalization level of the relevant administrators needs to be improved and the internal organizations are not well coordinated

Under the impetus of the internationalization of education, universities and colleges in Yunnan have established international exchange and communication institutions or sections specializing in external matters on international communication, but major part of the head or working staff in these organizations are selected from foreign language majors, officials and teaching staff with abroad-studying background. Problems rise from those inexperienced leaders and staff for a lack of knowledge in professional cross-border education system and higher education internationalization, these limitations become obvious when they carry out international higher education activities. In other colleges and universities, there still exist problems like cognition inconsistency and thought disunity in the process of international advance. For example, a international project is generally led and guided by the international exchange and communication institute or the international education college in some university, but very often, due to the improper allocation of resources or lack of coordination, other institutions usually find it difficult to understand and render support to such international project and the project will be obstructed by poor teaching effect and insufficient teaching staff.

\section{IMPLEMENTATION PATH OF INTERNATIONAL HIGHER EDUCATION EXCHANGE AND COOPERATION IN YUNNAN UNDER “THE BELT AND ROAD” INITIATIVE}

With the construction of "The Belt and Road", universities and colleges in Yunnan are duty-bound. Even though there are many difficulties to overcome, opportunities will be greater than challenges with the national strategy and location advantage of Yunnan.

\section{A. Strive for Macro-Support From the National Level and Specific Care From Local Governments}

Some of the challenges universities and colleges in Yunnan are facing in the constructing of "The Belt and Road" need macro guidance at the national level to be solved effectively, while others need the local government to attach great importance to cope with. The unfolding and boosting of "The Belt and Road" initiative and the requirements for universities and colleges to fit increasingly fierce international competition motivate universities and colleges to reform its administrative management system to rule and regulate legally. On one hand, we should rationalize the relationship between the government and universities and colleges to give them full autonomy in running, especially the power in international exchange and communication management. On the other hand, the establishment of a modern university system with Chinese characteristics should be pushed. The advancement of higher education's internationalization must be based on university's modernization. Universities and colleges should improve the internal governance structure, rule and administrate according to the articles of the university statues as guidance, carry out the President responsibility system under the leadership of the Communist Party Committee, fully play the role of academic organization, deepen the reform of management system and enhance the endogenous driving force of the development of internationalization of colleges and universities. Therefore, colleges and universities in Yunnan have to strive for attention and support at national level and local government level.

\section{B. Promote International Higher Education Exchange and Cooperation Based on Cross-Border Education Cooperation}

Sino-foreign cooperative education is an important way to promote the internationalization of education, and it is also a scientific experiment to introduce high-quality education resources to deepen the reform of education. "The Belt and Road" initiative has provided opportunities for Sino-foreign cooperative education in Yunnan and Sino-foreign cooperation will be a main choice for current cross-border education communication and cooperation among universities and colleges in Yunnan. To develop Sino-foreign education, universities and colleges in Yunnan should focus on these underdeveloped and badly needed subjects closely related with "The Belt and Road" initiative in China, and carry out multilateral cooperation with high-level universities in countries along the routes. In view of "The Belt and Road" initiative's important areas which involve transportation, information, energy, trade, finance, ecological environment protection, language, culture, science and technology, health and tourism, etc, universities and colleges in Yunnan should carry out service-oriented cross-border education with wellknown colleges and universities along the routes, set up high level Sino-foreign cooperation projects, speed up mutual degree recognition of the education qualification in both China and these areas and promote the joint training of high-level international talents. In addition, universities and colleges in 
Yunnan have a unique advantage in attracting abroad student from countries along the routes to study in China, but they still need to make efforts to improve the education level of master and doctor's degree.

\section{Cultivate International Versatile Talents}

All countries next-door to Yunnan Province are developing countries along the routes of "The Belt and Road", sharing similar levels on citizen's skills, science and culture, demands for comprehensive quality and challenges with us. To advance "The Belt and Road" initiative deeply and common development of countries along the routes, a "talent first" policy must go ahead. Yunnan is now taking the cultivating of creative international trade talents as the basis for the development of international construction to reform and adjust disciplines and specialties, focusing on cultivating professional talents to meet the huge shortage in opening situation. The talents should master local languages and cultures of these ASEAN countries, international rules and regulations as well as harbor international vision to supply high-level human resources for the construction of "The Belt and Road".

\section{Optimize Curriculum and Explore Education Reform at Deeper Level}

The internationalization of courses and majors is an essential element of education internationalization. Requirements for talents vary according to different regions, different countries and different levels of educational objectives and universalities and individualities co-exist. Aiming at great demands to develop their pillar industries, universities and colleges in Yunnan should design an international curriculum system focusing on geology, resources, energy, environment, ecology, etc. An updating teaching mode should also be set up to cultivate internationalized talents.

First of all, discipline settings must be conformed to meet the requirements. One is to adjust the disciplinary structure. To adapt to the economic and social development and the needs of international exchanges and cooperation, universities and colleges can draw lessons from successful experience abroad to break through the bondage of traditional disciplines, strengthen the intersection of different subjects, develop professional "Belt and Road" major, expand professional caliber, encourage development of interdisciplinary and edge disciplines to cultivate the students' comprehensive ability. Second, conditions for professional construction need to be greatly improved. By the advantages of "The Belt and Road" initiative, higher education in Yunnan can attract foreign investment and other resources, increase education investment, improve the existing administration and accelerate the construction and development of "brand-name" majors as well as characteristic specialty in universities and colleges.

Then, course content should be optimized. We will further build a curriculum system for international integration. Besides our traditional Chinese language and literature based on Chinese culture, the construction background, implementation keys, cooperation mechanism, rules and regulations of "The Belt and Road" initiative should be integrated into course design as well as each country's national history and culture, social economy, ethnic and religion. All these related factors and elements should be included and infiltrated into the content of the interdisciplinary professional education.

Finally, it is necessary to innovate and to create training mode to ensure the effectiveness of talent cultivating. On the one hand, universities and colleges in Yunnan can strengthen the cooperation with higher education institutions in countries along the routes, via education projects such as students exchanging, international students recruiting, practice teaching could be enhanced to provide better service for opening-up strategy of talent cultivation; on the other hand, young university students in Yunnan should be encouraged to participate in governmental and non-governmental international organization activities to develop their international vision, get familiar with the rules of international cooperation, customs, etc. as well as to promote their professional growth in practice.

\section{E. Improve the International Consciousness and Promote the Internationalization Level of Management Personnel}

The reasons behind the challenges faced by universities and colleges in Yunnan are complex and diverse, not only from the objective fact that their own development is insufficient, but also from the thin international consciousness of themselves. Therefore, universities and colleges in Yunnan should first raise the awareness of internationalization and make proactive efforts to take advantage of "The Belt and Road" initiative.

Effectiveness of policy implementation also depends on the management's ability to execute. Therefore, when selecting administrative staff for international education section, universities and colleges in Yunnan should focus on whether they have the professional background of cross-border education rather than just the ability to speak foreign languages. Higher education should take the path of internationalization, among which internationalization of management personnel is important guarantee. What we need is to train management staff to get familiar with not only common international educational management rules, especially the international education in Asia-Pacific region. In particular, universities and colleges in Yunnan can also hire higher education management experts from the world scope to practice advanced educational philosophy and management experience overseas and combine this with China's national conditions. Only the internationalization of higher education management in Yunnan Province has improved, can universities and colleges in Yunnan as well as China's higher education management system cope with the challenges brought by "The Belt and Road" initiative.

\section{REFERENCE}

[1] "Opinions on Well Doing Works of Education Opening in the New Period" [EB/OL].(2016-04-29)[2016-09-12]. http://news.xin-huanet.com/politics/2016-04/29/c_1118775049. htm.

[2] Notice on Promoting Education Action under "The Belt and Road" Initiative [EB/OL]. (2016-04-29) [2016-09-12]. http://www. moe. gov. cn/ srcsite/A20/s7068/201608/t20160811_274679.html.

[3] Liu Jin, Ha Mengyi. Turning Point of College Teaching Staff Mobility in East and West China under "The Belt and Road" Initiative [J].Chongqing Higher Education Research,2016 (5): 20-25. 